\title{
Clio
}

Women, Gender, History

$38 \mid 2013$

Working Women, Working Men

\section{Gender, collective bargaining agreements and skills in French industry in the first half of the twentieth century}

Genre, conventions collectives et qualifications dans l'industrie française du premier $\mathrm{XX}^{e}$ siècle

Laure Machu

Translator. Ethan Rundell

\section{OpenEdition}

Journals

Electronic version

URL: http://journals.openedition.org/cliowgh/286

DOI: $10.4000 /$ cliowgh.286

ISSN: 2554-3822

Publisher

Belin

\section{Electronic reference}

Laure Machu, " Gender, collective bargaining agreements and skills in French industry in the first half of the twentieth century », Clio [Online], 38 | 2013, Online since 15 September 2014, connection on 21 April 2019. URL : http://journals.openedition.org/cliowgh/286 ; DOI : 10.4000/cliowgh.286 


\section{Gender, collective bargaining agreements and skills in French industry in the first half of the twentieth century}

What did the pay scales that were developed in the first half of the twentieth century mean for French women factory workers? This question, which historians have begun to explore, constitutes the point of departure for the present article. ${ }^{1}$ Before answering it, it is worth recalling the historical background.

At the turn of the century, industrial wages still largely escaped negotiation between labor and employer unions. And although the pay hierarchies of the time were based on multiple criteria - age, sex, seniority - qualification or skill was not necessarily taken into account. In particular, women constituted a separate category in which wages sometimes depended entirely on age. ${ }^{2}$ As collective bargaining agreements expanded, especially in the interwar years, minimum pay scales based on the worker's recognized skill gradually became widespread. ${ }^{3}$ When they were negotiated, pay scales represented a victory for wage-earners who hoped for recognition of their skills. Their development required a prolonged effort to inventory the existing trades and jobs that were to be classified. It also presupposed reaching agreement regarding the criteria according to which skill was to be defined. A polysemic term, "skill" could just as easily refer to a formal certificate as to the degree of complexity of the tasks to be carried out in the workplace. As a result, the

\footnotetext{
Omnès 1997; Zancarini-Fournel 1993; Chenut 2010.

Beau 2004.

Machu 2011.
} 
measurement of skills as reflected in wages was subject to debates and conflicts regarding the value of a paper qualification or of the skills required in the performance of a job. However, judgments regarding the qualifications required for a given job could also vary depending on the sex of the person who held it. ${ }^{4}$ Recognition of skill was therefore the product of a series of social relations: on the one hand, relations between employer and trade union organizations and, on the other, relations between the sexes.

In order to examine the degree of skill respectively assigned men and women's work by trade and employer unions, the present article compares the negotiations that took place in the garment [vêtement] and metalworking industries in France in first half of the twentieth century. The garment industry was a sector traditionally dominated by women, in which the small size of firms remained an obstacle to attempts to rationalize production. In metalworking, expansion of the number of female workers coincided with an extension of the scientific organization of labor [sometimes known as Taylorization]. As far as the sources permit, I will attempt to reconstruct the debates that accompanied the development of pay scales. ${ }^{5}$ In keeping with the chronology that guided the gradual codification of pay scales, I will begin by examining the earliest agreements reached during and after the First World War, before considering the negotiation of collective bargaining agreements under the Popular Front of 1936, and the development of the Parodi-Croizat decrees following the Liberation (late 1940s).

\section{The First World War:}

\section{women are included in classification for the first time}

At the start of the twentieth century, collective bargaining agreements were still uncommon: in 1903, they only applied to around 5 per cent of the active population. ${ }^{6}$ They were the exclusive privilege of

4 Chenut 1996.

5 It is relatively rare to have access to the minutes of collective bargaining negotiations or projects that give one a precise idea of the actors' motivations. Cf. Machu 2011.

6 Rudischhauser 2005. 
recognized skilled trades, and of very little benefit to women. Above all, collective negotiation developed in urban artisanal occupations employing an almost exclusively male workforce, such as the printing and building trades. It was almost completely absent from the world of the factory. Like the largely female labor force of textile and shoemaking factories, the personnel of metalworking factories rarely benefitted from collective bargaining agreements. ${ }^{7}$

During the First World War, the joint consultation system established by the French state to oversee labor relations allowed for an extension of collective bargaining, to the benefit of the female workforce. Collective bargaining took place in various sectors, including the clothing, and metalworking industries, but also in chemicals and shoe manufacture. It was in the first two sectors, however, that the negotiation dynamic was most robust. The strikes of winter 1916-1917, in which women workers played an active role, led the Minister of Armaments, Albert Thomas, to intervene in setting working conditions and regulating conflicts. ${ }^{8}$ The first result of placing the workforce of the war factories under state supervision was the 16 January 1917 decision fixing wages there. ${ }^{9}$ The Ministry of Armaments' decisions revised the principles of labor classification, in line with the extension of the process of rationalization.

The first texts privileged a trade-based classification centered on the skilled worker [l'ouvrier professionne]. They distinguished between two groups: skilled or partially-skilled workers and non- or semiskilled workers. The latter had not undertaken an apprenticeship and were referred to as manouvres spécialisés. Skilled workers were ranked according to their mastery of the trade; experienced workers were contrasted with novices, known in French as "petites mains". ${ }^{10}$ The

7 For the years 1910-1912, 229 collective bargaining agreements were reached in construction, 15 in printing, 29 in the textile industry and 9 in clothing.

8 Robert 1995.

9 Viet 2002.

10 "Avis émis par le comité permanent de conciliation et d'arbitrage sur l'interprétation de la décision ministérielle du 16 janvier 1917 fixant la réglementation des salaires pour les fabrications de guerre, article 2", ministère de l'Armement et des Fabrications de Guerre ["Opinion issued by the permanent committee for conciliation and arbitration concerning the interpretation of the 
ministry decisions referred to "unskilled women" [femmes nonprofessionnelles] alongside other women working as "screw machine operators", "polishers" and "varnishers", all of whom were classified as skilled [professionnelles]. In the Paris region (but nowhere else), this promotion was consolidated by the definition of the female skilled worker as one "who has successfully undergone the same tests as those required of [male] skilled workers".

The decisions rapidly gave another meaning to the category of mancuvre spécialisé. The March 1917 general mechanics pay scale specified that workers unqualified to do the relevant trade test, and those assigned to machines were to be classified in this category. Thus, the hand caster was classified as skilled, while the machine caster was assigned to the category of mancuure spécialisé. ${ }^{11}$ The characteristics of the job thus determined the skill level to which it was assigned. For the male workforce, this understanding of skill entered by the back door: it is only to be found in pay scales. For the female workforce, by contrast, it was systematized, with the decisions of Fall 1917 giving a generic definition of the ouvrière spécialisée based on the type of work she was assigned. Thus, the 13 November 1917 decision specified that by "ouvrière spécialisée, we mean the woman worker who is suited to repetitive labor or to operating special machinery or equipment". ${ }^{12}$

As one can see, progress in the area of classification was ambiguous. In Paris, the decisions represented an undeniable advantage, since they recognized and affirmed the skills acquired by women workers. ${ }^{13}$ As requested in the proposal submitted by the Union Corporative des Mécaniciens de la Seine [Seine Mechanics'

16 January 1917 ministerial decision fixing the regulation of salaries for war manufacturing, article 2", Ministry of Armament and War Manufacturing]. Tarifs et réglementation des salaires applicables pour les fabrications de guerre de la région parisienne, Paris: Imprimerie nationale. 1917: 8-15.

11 "Décision du 2 mars 1917, tarifs des salaires de la métallurgie" ["Decision of 2 March 1917, Metallurgy Pay Rates"], ibidem: 24.

12 "Décision du 13 novembre 1917", ministère de l'Armement ["Decision of 13 November 1917", Ministry of Armament], Deuxième supplément au tarif des salaires applicables aux usines de guerre de la région parisienne, op. cit.: 10-16.

13 Omnès 2001. 
Corporative Union], women no longer fell under a single generic category. ${ }^{14}$ Henceforth, they were distributed among three skill levels. But the creation of the category of ouvrière spécialisée confirmed women's assignment to the new machine-tending jobs that had resulted from the division and automation of labor. Employing women in these jobs allowed them to be classified as doing jobs which did not require much skill. Indeed, employers believed that women were "naturally" made for just such repetitive and monotonous work. The adroitness and dexterity needed to carry out their jobs were overlooked and not considered to qualify them as being "skilled". ${ }^{15}$

In the area of remuneration, the 16 January 1917 decision set out the principle of equal pay and then immediately undermined it. For the same job, women were ultimately paid between 18 and 25 per cent less than men. ${ }^{16}$ Against trade unions which supported demands for pay equality - in the secret hope that this would lead to women's exclusion from the workforce- employers claimed that this differential reflected the additional costs of employing women. In contrast to the British case, French women's integration into the armament factories marked the end of thoughts of pay equality. ${ }^{17}$

Unlike in metalworking, the collective bargaining agreements reached in the garment industry in 1918-1919 (some of which were renewed until 1930) retained a trade-based definition of skill. The agreements inventoried several trades in which advancement reflected the acquisition of professional knowledge. At the summit of the hierarchy were the skilled trades of cutting and pressing. These were traditionally reserved for men who had undergone a long apprenticeship. ${ }^{18}$ The intermediary steps - the jobs of stitching and

14 Archives nationales (AN), 94 AP 138: letter from the Union corporative des mécaniciens de la Seine, 10 January 1917.

15 Downs 1995.

16 "Décision du 16 janvier 1917", ministère de l'Armement et des Fabrications de Guerre ["Decision of 16 January 1917", Ministry of Armament and War Manufacturing]. Tarifs et réglementation des salaires... op. cit:: 1-7.

17 Downs 1995: 110-113.

18 Cutting consisted of cutting fabric according to the pattern. Pressing consisted of ironing the article of clothing in order to give it a form once it had been tailored. 
piecing, performed by female piecers and stitchers - were considered unskilled tasks. ${ }^{19}$ Before the war, this strict partition was vigorously defended by trade unions dominated by skilled male workers, for whom female labor was a threat to men's skills and wages. Several strikes broke out demanding that women be prohibited from cutting and pressing. ${ }^{20}$

Nevertheless, the agreements reached in the postwar years opened some skilled trades up to women. In Lyon, the agreement signed in 1919 abolished sexual segregation. While pre-war rates tended to exclude women from cutting and pressing, ${ }^{21}$ this agreement entitled them to equal pay with men. ${ }^{22}$ In Lille, the agreements of 1919 and 1923 mention several female presser posts, ${ }^{23}$ but the cutting trades remained exclusively male. Moreover, a division of labor continued to be observed within pressing, with male pressers given the task of working with so-called "noble" materials, such as woolen cloth, while female pressers only worked with twill or canvas. ${ }^{24}$

The comparison between Lille and Lyon shows the degree to which progress for women workers depended on the general evolution of trade union structures on one hand, and women's advancement within trade unions on the other. In Lyon, agreements were negotiated by the Syndicat général du vêtement [Garment Industry Trades Union], an industry-wide union representing all categories of worker. As a union leader, Jeanne Chevenard signed all the texts negotiated in the interwar years. ${ }^{25}$ In Lille, the agreements

19 These two steps consisted of sewing and then assembling the pieces of fabric.

20 Office du travail [Labor office], Statistiques sur les grèves et le recours à la conciliation, 1906.

21 L'Ouvrier de l'babillement, 1906.

22 “Contrat de travail passé à la préfecture du Rhône le 5 juin 1919 entre le syndicat patronal des confectionneurs en gros et le syndicat de l'habillement du département du Rhône", L’Ouvrier de l'habillement, August 1919.

23 Collective agreement (CA) of the Lille wholesale garment industry, L'Ouvrier de l'habillement, June 1919.

24 L'Ouvrier de l'babillement, 1923.

25 Archives départementales (AD) Rhône, 10 M 582: file of the Syndicat de l'habillement du département du Rhône. In 1920, the union declared 3,500 members, 2,500 of whom were women. 
were negotiated by the Intersyndicale de l'habillement [Clothing Trade Union Group], created in 1919. The new structure brought together the Chambre syndicale des coupeurs [Cutters' Trade Union], the Syndicat des presseurs et des presseuses en confection [Trade Union of Garment Industry Pressers: both sexes] and the Syndicat des ouvrières en confection [Women's Garment Industry Trade Union], each of which enjoyed complete autonomy. ${ }^{26}$ The survival of the separate trade unions thus favored the maintenance of sexual segregation in the union and at work. In fact, the negotiation of collective bargaining agreements was exclusively conducted by the [male] cutters and pressers. As a professional trade union, the Chambre syndicale des coupeurs aimed to protect its members' skilled status via a Malthusian form of professional regulation. This depended on the defense of apprenticeship as the sole path for joining the trade, limiting the number of apprentices and excluding women from them. ${ }^{27}$

The First World War thus created the opportunity for women to be recognized as skilled workers. But little progress was in fact made. The strategies of worker and employer unions complemented one another. While the former defended male hegemony in the most highly skilled trades, the latter profited from women's relegation to the new jobs created by the division of labor to deny them skilled status.

\section{The Popular Front: improvement or regression?}

In most sectors, collective bargaining began to fall off in the 1920s, with employers once again determining wages. The Popular Front thus represented a break with the immediate past. The strike wave, followed by the 24 June 1936 law on collective bargaining agreements, resulted in the signature of thousands of agreements. Inspired by thinking on labor relations reform with origins in the aftermath of the First World War, the new legislation profoundly reorganized the status of collective bargaining agreements. In

\footnotetext{
26 Un comité intersyndical à prendre en exemple: Lille. L'Ouvrier de l'habillement. 1923.

27 AD Nord, M 595 103: rapport au Préfet du Nord sur la grève des ouvriers de la confection, 25 December 1931. The cutters categorically refused to allow employers freely to recruit young people and women.
} 
particular, it required them to contain a scale setting out the hourly pay for each occupational category. ${ }^{28}$ The principle of classifying workers thus became widespread. While this represented an undeniable advance for the working class, the degree to which it benefitted women remains to be seen.

\section{Permanence of the sexual division of labor}

The skill scales were determined in a gendered way: on the one hand, they excluded women from jobs defined as skilled; on the other, they tended to deny that skill was involved in those jobs women were allowed to perform. In keeping with the decisions of the First World War, the Parisian metalworking industry's collective bargaining agreement assigned two meanings to the notion of skill. "Professional workers" [ouvriers professionnels] exercised trades in which apprenticeship "can lead to award of a CAP [certificat d'aptitude professionnel, or vocational training certificate]". By contrast, specialized workers [ouvriers spécialisés, or OS] performed jobs that did not "require knowledge of a trade in which apprenticeship can lead to award of a CAP". ${ }^{29}$ In one case, the classification was defined by the certificate. In the other, it was defined by the characteristics of the post. For the OS was not defined by the absence of an apprenticeship, but rather by his/her place in the division of labor, as indicated by the distinction between "OS machine posts" and "OS assembly and miscellaneous" posts - the former being more highly remunerated.

As no CAP existed for women in metalworking, the preference given to the CAP as a path for accessing the status of professional worker was to their disadvantage. ${ }^{30}$ Job-specific descriptions of skill further disadvantaged them. The worker's relationship to the machine was the primary criterion chosen for distinguishing among jobs. Jobs that only required simple manual operations were exclusively held by women. Thus, in electrical construction, there were only "female wire spoolers by hand" and "female copper winders by hand". Though

\footnotetext{
28 Machu 2011.

29 AN F 22 1633: CC des industries métallurgiques de la région parisienne, 12 June 1936, article 19.

30 Castets 2003.
} 
held by both men and women, the job of "copper winder by machine" was classified "OS machine" when held by men, and "OS assembly and miscellaneous" when held by women. ${ }^{31}$ This inequality reflected a denial of the skill demanded by the specialized and repetitive jobs performed by women. Employers tended to regard the qualities required for this type of work as innate to the female sex; women thus had no claim to special remuneration..$^{32}$ By virtue of this principle, which was applied in other sectors as well, ${ }^{33}$ work performed on "small motorized machines" was systematically classified OS assembly and miscellaneous. By contrast, work requiring physical strength - a masculine trait - was seen as justifying additional remuneration. "Heavy laborers", an exclusively masculine category, were paid 20 per cent more than "ordinary operators".

In contrast to metalworking, the Popular Front reforms confirmed women's access to skilled trades in the garment industry specifically, those of presser and cutter. But the feminization of skilled jobs did not necessarily constitute a resounding advance. While the texts recognized the progressive mechanization of cutting and pressing, this work continued to be marked by a sexual division of labor, with machine-tending posts reserved for women. In Paris, the men's garment industry agreement included an exclusively female category - "female machine cutter" - which was paid less per hour than that of female hand cutter. ${ }^{34}$ In Lyon, the agreement only mentioned the post of "male presser", with female presser jobs divided between the "small press" and the "large press" - the former being paid 10 per cent less than the latter. ${ }^{35}$

31 AN CAC 1986 0170, article 200: Sous-groupe A, construction machines et appareillage, définitions proposées.

32 Downs 1995: 222-223.

33 The same argument was used in the hosiery [i.e. knitted goods] industry of Troyes, where the jobs performed by women on small machines were systematically depreciated relative to the jobs performed by men on larger machines. Cf. Chenut 2005: 382-383.

34 AN F 22 1615: CC de la confection pour homme de la région parisienne, 18 July 1936.

35 AD Rhône, 5 UP 35: CC de la confection en gros de Lyon, 16 October 1936. 


\section{Expansion and hierarchization of female tasks}

As victims of a distribution of tasks that relegated them to the least skilled jobs, did women nevertheless profit from the Popular Front agreements in such a way as to improve their position within the division of labor? In a number of sectors, collective bargaining agreements in fact brought significant regression. The Parisian metalworking industry agreements unquestionably accentuated the sexual division of labor. Running counter to a trend of increasing recognition of women as skilled workers since the First World War, the Popular Front's collective bargaining agreement reduced the spectrum of women's skilled trades. The jobs of woman production grinder, metal turner and milling-machine operator (all of which were previously mentioned in employer surveys) no longer featured in the collective bargaining agreement of $1936 .{ }^{36}$ Other trades were downgraded. Women enamellers, who in 1930 were paid 20 per cent more than specialized workers, became "women enamel coaters", a job classified as OS assembly and miscellaneous. ${ }^{37}$ As in Paris, the Saint-Etienne metallurgical agreement downgraded the jobs of most skilled female workers. ${ }^{38}$

But the deepening sexual division of labor manifested in these texts should not obscure the progress brought about by agreements in other sectors or regions. Many agreements allowed the spectrum of female tasks to be enlarged and hierarchized. By taking a task's degree of difficulty into consideration, these texts allowed for greater nuance in the ranking of women's work. The wartime pay scales and interwar statistics of the Lyon metals industry only take note of three groups: mancuvres and mancuvres spécialisées [unskilled women operatives]; 39 "women having some skills"; and "women with specialized skill". ${ }^{40}$

36 Omnès 1997: 140.

37 Groupement des Industries Métallurgiques (GIM), Enquête sur les taux horaires des salaires, January-February 1930.

38 Zancarini-Fournel 1993: 182.

39 AD Rhône, 10 M 586: recensement des salaires et des professions effectué par la préfecture du Rhône (1928); AN F 22 1633: CC des industries métallurgiques du Rhône, 25 July 1936.

40 AD Rhône, 10 M 586: Chambre syndicale des industries métallurgiques du Rhône, Statistique de payes, March 1935. 
The Popular Front agreement classified women into four groups, depending on the characteristics of their job. The first of these groups included unskilled laborers, storekeepers and those performing simple manual tasks. ${ }^{41}$ The second was that of the "machine-minders and hand assembly workers". The third brought together women operating "small presses" and performing "light machine work", a group to which women welders, staplers and paintsprayers were annexed. The fourth group, finally, consisted of women who worked on "large presses and large machines", performing "demanding work on high-risk machines". A job's difficulty and/or demanding nature was thus recognized and rewarded. These four groups were respectively paid 3.40, 3.75, 4.10 and 4.40 francs per hour, ${ }^{42}$ making for a 29 per cent pay disparity between the least skilled women workers and those who handled heavy machinery.

\section{A wage policy favorable to women}

Furthermore, a wage policy favorable to women partly compensated for the maintenance of the sexual division of labor. Under the impact of the Matignon Agreements' readjustment of abnormally low wages, the Popular Front's collective bargaining agreements introduced a reduction of pay differentials for equal work. The scale of the reduction nevertheless varied between sectors. In both Paris and Lyon, the metalworking industry's agreements established a 20 per cent wage gap. For women workers in Lyon, the pay differential with their masculine counterparts was thus reduced by half. In the clothing industry, by contrast, the male-female wage differential was still 50 per cent. In this sector, the reduction of pay discrepancies was less systematic. For the trained personnel of the men's garment industry, wage differentials remained almost unchanged between 1918 and 1936.43

An examination of the trades and wages allotted to the female workforce thus reveals that collective bargaining agreements were far from unanimously favorable to women. This disregard, as well as the

\footnotetext{
41 AN F 22 1633: CC des industries métallurgiques du Rhône, 25 June 1936.

42 AN F 22 1633: CC des industries métallurgiques du Rhône, 25 June 1936.

43 The differential oscillated between 35 and 40 per cent for cutters in Paris and remained at 50 per cent for the male and female pressers of Lille.
} 
variable effect of collective bargaining agreements on the situation of the female workforce, is explained by the fact that both employer and labor unions pursued strategies unfavorable to women.

\section{Trade unions and women's wages during the Popular Front}

Although they took part in the strikes at the time of the Popular Front, ${ }^{44}$ women were marginalized in the negotiations because fewer of them were present as trade union representatives. ${ }^{45}$ While women's participation in negotiations would not on its own have guaranteed that the resulting agreement would be to their advantage, there is no doubt that their absence left the way open to discriminatory discourses and practices. Neither at summit (confederal) level nor within individual trades unions was reducing gender inequalities a priority. Though this attitude may have been the result of indifference, or of a misunderstanding of the realities of sexual segregation, it more likely reflected the fact that, like the ideology of the "male breadwinner", 46 distrust of the female workforce lived on within the French labor movement. It should be recalled that, in 1933, the CGT demanded equal pay for men and women in order to put an end to "conflict between the sexes on the labor market" while at the same time asking for an increased family allowance in order to free mothers from the need to seek "extra income" - this latter on the grounds that one could not absolutely forbid women's work. ${ }^{47}$ At the individual trade union level, sexual inequalities were part of a whole range of wage inequalities. Priority was given to reducing regional inequalities by reaching a national agreement, rather than to reducing inequality between the sexes. ${ }^{48}$

In most branches, the classification scales proposed by worker representatives at the local level seem indicative of a strategy that consisted of demanding better pay for women - perhaps in order to eliminate female competition - while at the same time preserving

44 Blum 1978; Sirot 1994.

45 Zylberberg-Hocquart 1978; Frader 1996; Denis-Morillon 1981; Poggioli 2012.

46 Frader 2008.

47 CGT. Congrès confédéral de Paris. Paris: Éditions de la confédération générale du travail. 1933: $307 \mathrm{ff}$.

$48 \quad$ Margairaz \& Tartakowsky 2006. 
male prerogatives in access to skilled status. ${ }^{49}$ In the Parisian metalworking industry, where the trade union seems to have admitted the inevitability of women's employment, ${ }^{50}$ the union proposals appeared advantageous from the point of view of the overall level of remuneration agreed. But the text put sexual segregation into practice, failing to address the grievances of the female workforce, which had been expressed in the formal demands of the female section of the metalworkers' union, established in 1935. In the first place, the proposals did not mention the spectrum of female jobs specified by the Groupement des Industries Métallurgiques [GIM: Organization of Metallurgical Industries] wage inquiry, and by the formal demands drawn up by women workers. Next, the trade union project reduced female paint sprayers, fitters, measurers, winders and so on to the hourly rate of the "all-category female worker", despite the fact that, in April 1936, they were paid more highly than female OS workers. ${ }^{51}$ The women workers called for these women to be paid 30 per cent more than the female ouvrières spécialisées. ${ }^{52}$

The inequalities left intact by the collective bargaining agreements do not seem to have provoked protest among women workers, either because it was considered that there had been an overall improvement or because their silence reflected their subordinate position within the labor movement. At the Liberation, by contrast, the greater number of women trade union officials allowed for some progress to be made.

\section{The Parodi-Croizat decrees: equality won?}

Following the Liberation, classification scales were included in ministerial decrees. In contrast to the collective bargaining

49 Chenut 2010. See also the example of the Troyes textile industry. The author indicates that the trade union's leadership negotiated an agreement that protected the jobs reserved for men. Saint-Etienne activists were for their part driven by a "misogynistic Malthusianism" that defended the "natural need for distinct work spaces for men and women”. Cf. Burdy, Dubesset \& Zancarini-Fournel 1997.

50 Frader 2008: 212.

51 Projet de contrat collectif ouvrier. L'Humanité. 5 June 1936.

52 Le Métallo. June 1935. 
agreements of the Popular Front, the Parodi-Croizat decrees consisted of a vast, state-directed effort to impose order on wages. The decrees were thus national in scale and were all issued in accordance with the same procedure: a "decree fixing wages" defined the general principles of remuneration and the generic categories of semi-skilled/unskilled and skilled worker; "classification decisions" then implemented the classification of jobs within the generic categories supplied by the decree. Although this period is thought of as one of "wage statism", ${ }^{33}$ the decrees were elaborated in tripartite collaboration between trade unions, employer organizations and representatives of the state. The reorganization of wage scales took place in a context that was relatively favorable to women. In addition to obtaining the right to vote, their demands acquired greater visibility within the worker's movement. ${ }^{54}$

Though of crucial importance, the process by which these decrees were elaborated has received little attention. ${ }^{55}$ While the question of continuity with the hierarchies of the collective bargaining agreements of the Popular Front has been raised, ${ }^{56}$ the wages and skills attributed to the female workforce have not been examined. For women, the elaboration of the Parodi-Croizat decrees is a more significant moment than the negotiations of the Popular Front.

Initially, the decrees had difficulty establishing the principle of wage equality. The decree of 12 April 1945 regarding wages in the metal industry of the Paris region noted that, "given the same working conditions and productivity, remuneration must be calculated on the same bases for men and for women." Yet, even as it proclaimed the principle of parity, the text reined in its scope. Indeed, it specified that "in no case shall the minimum rates of women's wages be more than 10 per cent less than men's rates." 57 The

53 Sellier 1983: 187.

54 Olmi 2005.

55 This lacuna is in part due to the fact that the Labor Ministry's archives are closed for this period. The collections have not been available for consultation since 2003 .

56 Saglio 2007.

57 "Arrêté du 31 mai 1945 relatif aux salaires dans les industries des métaux", Direction du Travail, Salaires et classifications professionnelles, fascicule: industries $d u$ vêtement. Paris: Imprimerie des journaux officiels. 1946: 9-18. 
principle of a 10 per cent differential was debated in the Central Wage Commission. Workers' representatives spoke in favor of wage equality and it was the employers who asked that discrimination be maintained. The arguments were rather classic, emphasizing the inferiority of the work performed by women and denying their skill. ${ }^{8}$ In the end, the Gaullist Minister of Labor, Alexandre Parodi, decided the debate in favor of the employers. In contrast to the Popular Front, the measure was sharply denounced in the columns of the CGT press. With the Parodi decrees, women activists protested, "a woman is legally paid less than a man solely because she is a woman." Women's committees sent several delegations to the Ministry of Labor to ask for the differential to be abolished. ${ }^{59}$ Speaking at a CGT conference, Marie Couette brought to the vote a resolution in favor of wage equality. ${ }^{60}$ Finally, on 10 July 1946, Ambroise Croizat, the new communist Minister of Labor, signed the decree doing away with the 10 per cent differential.

While the decrees accepted the principle of wage equality in cases of equal skills, the corresponding classification decisions offered the possibility of maintaining a gendered skill scale. The negotiation of classification decisions therefore played a major role in consolidating the principle of male-female equality. In the metal and clothing industries, they allowed women to maintain - and even on occasion improve - the positions they had acquired. In metalworking, the decree adopted the rules established by the Parisian metals industry agreement of 1936. The text thus retained a classification consisting of three categories: unskilled worker/laborer, partially skilled worker [ouvrier professionnel and skilled journeyman, i.e. a worker having served an apprenticeship. In the last of these categories, the reference to the CAP was retained. This "formal" definition of the trade excluded women from access to the qualification. However, for certain jobs, the scale's architecture forbade attributing rates of pay that were intermediary between those for the OS and professional

58 AN CAC 1976 0122, article 292: procès-verbal de la séance de la commission nationale des salaires du 10 mars 1945.

59 Marie Couette. À travail égal, salaire égal. La Vie ouvrière. 19 October 1945.

60 Olmi 2005. 
categories. The decree thus allowed for a catch-all category of "assimilated to skilled workers" [assimilés professionnels] to accommodate jobs that, though not recognized as fully skilled worker posts, were nevertheless more highly remunerated in 1936 than the OS category. ${ }^{61}$ Around fifty posts were classified in the "assimilated to skilled workers" category. By taking the gains of 1936 into account, this "practical classification" was advantageous to women; it allowed women's jobs regarded as skilled that had survived in the Parisian agreement to be preserved. The female "all-purpose spooler" and "polisher" and the "woman wire-welder" thus continued to be classified as skilled women workers. The maintenance of these jobs for women seems to have been partly due to the action of worker representatives within the classification commissions. ${ }^{62}$

While the metalworking industry privileged continuity with the Popular Front, the men's garment industry [ready-made tailoring] broke decisively with the past. The classification decision no longer classified the workforce by acquired trade status, but rather in terms of posts held and tasks performed. Thus, the scale no longer mentions the term "cutter", but rather jobs that involved cutting by hand, now classified in the first rank of the fourth category. These were listed as follows: "cloth quilting, canvas tailoring and all lining tracing; all lining cutting with handheld scissors or circular blade machine; unbinding interior cloth and cotton or similar lining with vertical blade machine". The scale no longer made reference to trades, but rather hierarchized tasks by their degree of difficulty. These new criteria, the origin of which for the moment remains unknown, put an end to the privileges and hierarchies that had governed the trade's customary organization - the superiority of cutters over pressers, for example, or the exclusion (still in effect at the time of the Popular Front) of women from certain trades. At the local level, male workers strongly opposed this aspect of the reorganization. ${ }^{63}$ Referring to the disputes to which the new

\footnotetext{
61 Saglio 2007.

62 AN CAC 1896 0170, article 209: constructions électriques, compte rendu de la réunion du 15 juin 1945.

63 L'Habillement, August and September 1946.
} 
classification of the men's garment industry had given rise, the Féderation nationale des fabricants français de confection [National Federation of French Garment Manufacturers], which had representatives in the sub-committee responsible for classifications, denounced these attempts to conserve local advantages as severely undermining the impact of the wage reorganization. ${ }^{64}$

For the female workforce, the classification scales contained in the collective bargaining agreements and, later, the Parodi-Croizat decrees, represented a two-edged asset. While the scales developed by British employers in the interwar years continued to classify women workers into a common category in which age was the only variable, the extension of collective bargaining in France cast light on the variety of tasks performed by women in many different sectors and the skills these tasks required. The development of scales coincided with a policy of increased pay and allowed the differentials with men's wages to be reduced. But the scales legitimated the sexual frontiers of the division of labor. Women metal workers were excluded from the most highly skilled posts and confined to the lower end of the skill hierarchy. While women workers in the clothing industry had access to skilled trades, it was never on an equal footing with men. The persistence of this segregation reflected a denial of the skill involved in the kinds of tasks demanded of women workers. More precisely, assigning the new posts that resulted from the division and mechanization of labor to women allowed them to be described as unskilled. In this respect, the attribution of skill to a job was inseparable from the sex of the person who occupied it.

Examining the course of negotiations over a middle term period reveals the complex interplay of the strategies adopted by the actors involved in defining skill. Trade unions and the state only belatedly became involved in promoting skilled status for women. The attitude

64 De la reclassification des travaux. Bulletin de l'industrie du vêtement masculine. 15 January 1946. 
of labor unions can partly be seen as a response to the strategy of employers, for whom the feminization of the workforce represented an opportunity to pay lower wages. But it was also the product of a certain indifference - even hostility - towards the female workforce that lasted until the Popular Front. In this context, significant progress was only achieved with the Liberation.

Translated by Ethan RUNDELL

\section{Bibliography}

BEAU, Anne-Sophie. 2004. Un Siècle d'emplois précaires. Paris: Payot.

BLum, Françoise. 1978. Féminisme et syndicalisme : les femmes dans la Fédération de l'habillement. MA thesis, Université de Paris I.

Burdy, Jean-Paul, Mathilde Dubesset, and Michelle Zancarini-Fournel. 1997. Rôles, travaux et métiers de femmes dans une ville industrielle: Saint-Étienne, 1900-1950. Le Mouvement social 140: 27-53.

CASTETS, Jean. 2003. Genre et mixité des certifications professionnelles d'une guerre à l'autre. Clio. Histoire, Femmes et Sociétés 18: 143-153.

Denis-Morillon, A. 1981. Les femmes et le syndicalisme dans la Fédération CGT de l'habillement. MA thesis, Université de Paris I.

Downs, Laura Lee. 1995. Manufacturing Inequality: gender division in the French and British metalworking industry: 1914-1939. Ithaca, London: Cornell University Press.

FrADER, Laura. 1996. Femmes, genre et mouvement ouvrier en France aux XIXe et $\mathrm{XX}^{\mathrm{e}}$ siècles : perspectives et recherche. Clio. Histoire, Femmes et Sociétés 3: 223-244.

- 2008. Breadwinners and Citizens: gender in the making of the French social model. Durham: Duke University Press.

Chenut, Helen Harden. 1996. The gendering of skill as historical process: the case of French knitters in industrial Troyes (1880-1939). In Gender and Class in Modern Europe, ed. Laura Frader and Sonya O. Rose, 77-107. Ithaca: Cornell University Press.

- 2005. The Fabric of Gender: working-class culture in Third Republic France. University Park, PA: Pennsylvania State University Press.

MACHU, Laure. 2011. Les conventions du Front populaire. Construction et pratiques du système français de relations professionnelles. Doctoral thesis. Université de Paris Ouest-Nanterre. 
Margairaz, Michel, and Danielle Tartakowsky. 2006. L'Avenir nous appartient. Paris: Larousse.

OLMI, Janine. 2005. Les femmes dans la CGT 1945/1985. Stratégie confédérale et implication départementale. Doctoral thesis. Université de Nancy 2.

OMnÈs, Catherine. 1997. Ouvrières parisiennes: marchés du travail et trajectoires professionnelles au XX siècle. Paris: Éditions de l'EHESS.

- 2001. Qualifications et classifications professionnelles dans la métallurgie parisienne, 1914-1936. Revue du Nord 15: 307-322.

Poggioli, Morgan. 2012. À travail égal, salaire égal ? La CGT et les femmes au moment du Front populaire. Dijon: Presses universitaires de Dijon.

Robert, Jean-Louis. 1995. Les Ouvriers, la patrie et la révolution, Paris, 1914-1919. Paris: Les Belles Lettres, coll. «Annales littéraires de l’Université de Besançon », n592.

RudischHAuser, Sabine. 2005. Tarifvertrag und bürgerliche Öffentlichkeit. Überlegungen zu einer vergleichenden Geschichte der Anfänge des Tarifrechts I, Deutschland und Frankreich 1890-1918/1919.

http://www.forhistiur.de/zitat/0511 rudischhauser.htm.

SAgLIO, Jean. 2007. Les arrêtés Parodi-Croizat sur les salaires: un moment de la construction de la place de l'État dans le système de relations professionnelles. Travail et Emploi 111: 53-73.

SELlier, François. 1983. La Confrontation sociale en France, 1936-1981. Paris: Presses universitaires de France.

SIROT, Stéphane. 1994. Les conditions de travail et les grèves des ouvriers à Paris de 1919 à 1935. Doctoral thesis. Université Paris 7.

VIET, Vincent. 2002. Le droit du travail s'en va-t-en guerre (1914-1918). Revue française des Affaires sociales 1: 155-167.

ZANCARINI-Fournel, Michelle. 1993. Collective agreements in France in the 1930s: products, territories, scales. The Saint-Étienne example. In Governance, Industry and Labour Markets in Britain and France: the modernizing state in the mid-twentieth century, ed. Noel Whiteside and Robert Salais, 178-192. London \& New York: Routledge.

Zylberberg-HocQuart, Marie-Hélène. 1978. Féminisme et syndicalisme. Paris: Éditions Anthropos. 